\title{
AC 2011-118: OUTCOME ASSESSMENT OF LIBERAL EDUCATION SKILLS
}

\section{Tom A. Eppes, University of Hartford}

Tom A. Eppes is Associate Professor of Electrical and Computer Engineering at the University of Hartford. He earned a Ph.D from the University of Michigan and an M.S. degree from Texas A\&M University. His research interests are fiber optic communications, photonics, laser manufacturing processes, multiphysics modeling, and remote laboratories.

\section{Ivana Milanovic, University of Hartford}

Ivana Milanovic is Associate Professor of Mechanical Engineering at the University of Hartford. She earned a Ph.D. from Polytechnic Unviersity, New York, and an M.S. degree from the University of Belgrade. Her research interests are vortical flows, computational fluid dynamics, multiphysics modeling, and collaborative learning strategies.

\section{Frederick Sweitzer, University of Hartford}

Assistant Provost and Dean of Faculty Development 


\title{
Outcome Assessment of Liberal Education Skills
}

\begin{abstract}
Our regional accrediting body now requires outcome assessment of general education outcomes. Because of this mandate, and our new mission at the University of Hartford to prepare students to acquire the knowledge, skills, and values necessary to thrive and be engaged in a pluralistic, complex world, we have undertaken a project to develop and assess core liberal education outcomes. This paper describes the planning and actions thus far to meet these new requirements at the university and specifically in our engineering programs. We have begun to expand outcome assessment to include five "intellectual and practical skills," specifically, critical and creative thinking, inquiry/analysis, problem-solving, and information literacy. VALUE rubrics are being used as part of the process to ascertain where the best opportunities are to measure student achievement within the engineering and technology programs. An assessment framework is presented and successful pilot results are discussed.
\end{abstract}

\section{The Challenge}

Our regional accrediting body, New England Association of Schools and Colleges (NEASC), now requires assessment of general education outcomes, and further mandates that undergraduates demonstrate competence in written and oral communication; the ability for scientific and quantitative reasoning, critical analysis and logical thinking; and the capability for continuing learning, including information literacy. ${ }^{1}$ As a university, we aspire to promote and integrate excellence in liberal and professional education. We have, therefore, undertaken a project to identify a series of core undergraduate learning outcomes, to be addressed and assessed both in general education and in the majors. These outcomes will help our students develop the knowledge, skills, and habits of mind critical to meeting the demands of the workplace and functioning as contributing citizens in society. ${ }^{2,3,4}$ Nine intellectual and practical skills have been selected: oral/written communication, quantitative reasoning, critical and creative thinking, inquiry/analysis, problem-solving, teamwork, and information literacy. In the College of Engineering, Technology and Architecture, most engineering programs are currently accredited by the Accreditation Board for Engineering and Technology (ABET). Because of ABET standards, four skills, namely oral/written communication, quantitative reasoning and teamwork are already being assessed. However, the remaining five skills are incremental with no process in place to formally measure student achievement. This paper describes the planning and activities undertaken to meet this new requirement along with preliminary results from a recent pilot.

Our College is part of the University of Hartford, a private institution with about 4500 undergraduate students of which 800 are enrolled in engineering (E) and engineering technology (ET) programs. Bachelor of Science degrees, accredited by the Engineering Accreditation Commission (EAC) of ABET, are offered in 6 majors: Acoustical Engineering \& Music (new), Biomedical, Civil, Computer, Electrical and Mechanical Engineering. Within the last 10 years, 3 of the above programs were accredited for the first time. Three of five undergraduate ET programs, accredited by the Technology Accreditation Commission (TAC) of ABET, are available in the following majors: Architecture, Electronic and Mechanical Engineering 
Technology. The $11 \mathrm{E}$ and ET programs, as well as a Masters program with 150 students, are administered by 4 departments with a combined fulltime faculty of 38 .

Within E and ET programs, there is a fine balance between courses preparing students for the specific technical demands of the profession and non-technical courses that belong to the category of general education. Since we offer four year programs with a relatively narrow range of credit hours (125 to 135), an increase in one area must for the most part be offset by a decrease in another. We periodically re-visit program curricula to determine if and what kinds of changes are needed. ${ }^{1}$

The current outcome assessment process for E and ET programs is primarily designed to meet the requisite ABET Criteria $3(\mathrm{a}-\mathrm{k})$ requirements. Evaluation is concentrated on $3^{\text {rd }}$ and $4^{\text {th }}$ year courses and measures performance in specific embedded assignments within the core area, i.e. those most relevant to the major and taught within the College. Core courses may be classified as one of the following 5 types:

- Theoretical - 3 or 4 semester credits, largely lecture-based, and devoted to an advanced topic within a specific discipline such as thermodynamics or wireless communications.

- Experiential - Laboratory-oriented course equivalent to 1 to 3 semester credit.

- Professional - Included for all E majors and covers topics common to disciplines. Currently, ET programs do not have a professional component.

- Capstone - An integrating experience of 3 to 6 semester credits and taken in the final year of study in which the student completes an unscripted design project.

- Other - A technical communication course sequence focused on written and oral skills taken by all ET majors.

Broader Educational Context

The changes being mandated by NEASC are part of a much larger policy initiative that is national in scope. Most, if not all regional accreditation boards are undertaking similar efforts in their respective areas of authority. Over the last decade, concern over the quality of higher education in the United States (U.S.) has been widely expressed and debated. Faced with mounting evidence that we no longer lead the world in postsecondary achievement, educational proponents have advocated far-reaching efforts to increase the number and quality of higher education graduates. $^{3,4,5}$

The Association of American Colleges and Universities (AACU), representing over 1,100 colleges and universities of all types and sizes, and whose sole focus is the quality of learning, asserted a fundamental question: What do college students need to learn and be able to do? ${ }^{4}$ In 2005, the AACU launched an initiative, Liberal Education and America's Promise (LEAP): Excellence for Everyone as a Nation Goes to College. ${ }^{5}$ LEAP challenges schools, colleges, and universities to fulfill the promise of liberal education in a "new century marked by increasing global complexity, interconnectedness and rapid change.” LEAP further recommends that students acquire the following four blocks of essential learning abilities: 
- Knowledge of human cultures and the world through the study of natural and social sciences, mathematics, humanities, histories, languages and the arts.

- Intellectual and practical skills: inquiry/analysis, critical and creative thinking, written and oral communication, quantitative reasoning, information literacy, teamwork and problem solving.

- Personal and social responsibility spanning civic knowledge and engagement (local and global), intercultural knowledge and competence, ethical reasoning and action, foundations and skills for lifelong learning.

- Integrative and applied learning including synthesis and advanced accomplishment across general and specialized studies.

Secretary of Education, Margaret Spellings, announced in 2005 the formation of the Commission on the Future of Higher Education and charged it with developing a comprehensive national strategy for postsecondary education. The Commission issued a report, A Test of Leadership: Charting the Future of U.S. Higher Education. ${ }^{2}$ One finding noted that the quality of student learning at U.S. colleges and universities is inadequate and, in some cases, declining. Shortcomings were found in learning outcomes and core literacy skills. How learning outcomes are measured complicates public policy because program completion and higher-level achievement are not one and the same., 6 This returns us to the question: "What do college students need to learn and be able to do?" that was revisited in 2007 by the AACU. ${ }^{8}$ On an international scale, the Organization for Economic Co-operation and Development (OECD) provided a perspective on current practices in standardized assessment across five countries and proposed a typology of higher education learning outcomes. ${ }^{9}$

Improving the performance of post secondary institutions has increasingly taken center stage in U.S. economic recovery plans. In remarks by President Barack Obama on the American Graduation Initiative, a top priority is to ensure that the U.S. has the highest percentage of college-educated workers in the world. ${ }^{10}$ However, to make excellence truly inclusive, quality must drive commitment to college completion. ${ }^{3}$

The implications of LEAP on the engineering and technology higher education community leads to the following question: What is the purpose of liberal education and how should it permeate our curricula? Newman's approach to liberal education is that of "enlargement or expansion of the mind," a process in which university education helps students develop skills necessary for intellectual expansion. ${ }^{11}$ Heywood ${ }^{12}$ introduced the idea of engineering literacy being a component of liberal knowledge as defined by Newman. Harper et al. ${ }^{13}$ conducted a survey of engineering administrators and found that substantial support exists for integrating the goals of liberal and professional education. They concluded that administrators view liberal learning as a path to prepare students to become productive professionals, community citizens, and leaders in a diverse and socially dynamic world. Further, there is ample evidence that liberal learning outcomes are most effectively achieved when undertaken as a partnership between the often separated curricular spheres of general education and the major. ${ }^{14}$ 
Incremental Assessment Requirements

Given this broad educational context that involves both public and private initiatives, we now examine the new requirements by NEASC which equate specifically with the "intellectual and practical" skills block described above. Included are 9 skills: 4 of which are currently being assessed leaving 5 that are incremental to the process now in place. We do not address the other three blocks: knowledge of human cultures, personal and social responsibility or integrative/applied learning.

Oral/written communication and teamwork, are currently assessed thoroughly to meet ABET requirements. These 3 abilities have long been identified as important for $\mathrm{E}$ and ET graduates and are strongly supported by employers. A variety of assignments and assessment tools have been developed to both promote development and provide a good measure of achievement. Additionally, the task of assessing quantitative reasoning appears straightforward given the high level of concentration in core E and ET courses.

Our efforts are centered on inquiry/analysis, critical and creative thinking, information literacy, and problem solving as defined in Table 1. These 5 skills pose an outcome assessment challenge since their development largely occurs during the first two years of study. In the final two years, this foundation is critical to success in advanced technical courses with integrative experiences. Faculty members who teach upper level courses do not explicitly assess any of the 5 skills. In addition, the assignments themselves may not be designed appropriately. As a result, changes at the course and curricular levels will likely be necessary.

Table 1. Skill definitions. ${ }^{17,18}$

\begin{tabular}{|l|l|}
\hline \multicolumn{1}{|c|}{$\begin{array}{c}\text { Intellectual and } \\
\text { Practical Skills }\end{array}$} & \multicolumn{1}{c|}{ Definition } \\
\hline Inquiry and Analysis (IA) & $\begin{array}{l}\text { Systematic process of exploring issues, objects or works through the } \\
\text { collection \& analysis of evidence that results in informed conclusions } \\
\text { or judgments. Analysis is the process of breaking complex topics or } \\
\text { issues into parts to gain a better understanding of them. }\end{array}$ \\
\hline $\begin{array}{l}\text { Critical Thinking } \\
\text { (CT) }\end{array}$ & $\begin{array}{l}\text { Habit of mind characterized by the comprehensive exploration of } \\
\text { issues, ideas, artifacts, \& events before accepting or formulating an } \\
\text { opinion or conclusion. }\end{array}$ \\
\hline $\begin{array}{l}\text { Creative Thinking } \\
\text { (C) }\end{array}$ & $\begin{array}{l}\text { Both the capacity to combine or synthesize existing ideas, images, or } \\
\text { expertise in original ways and the experience of thinking, reacting, \& } \\
\text { working in an imaginative way characterized by a high degree of } \\
\text { innovation, divergent thinking, \& risk taking. }\end{array}$ \\
\hline $\begin{array}{l}\text { Information Literacy } \\
\text { (IL) }\end{array}$ & $\begin{array}{l}\text { Ability to know when there is a need for information, be able to } \\
\text { identify, locate, evaluate, \& effectively \& responsibly use \& share } \\
\text { that information for the problem at hand. }\end{array}$ \\
\hline $\begin{array}{l}\text { Problem Solving } \\
\text { (PS) }\end{array}$ & $\begin{array}{l}\text { Process of designing, evaluating \& implementing a strategy to } \\
\text { answer an open-ended question or achieve a desired goal. }\end{array}$ \\
\hline
\end{tabular}


Part of LEAP was the development of a set of rubrics called Valid Assessment of Learning in Undergraduate Education (VALUE). ${ }^{17,18}$ These rubrics are intended for institutional-level use in evaluating and discussing student learning within a basic framework of expectations.

Consequently, each of the "intellectual and practical skills" defined in Table 1 above have an associated VALUE rubric which we found helpful in two ways. First, we were able to determine if our methodologies could be improved by switching to a new rubric. Second, pilot assessment of those skills incremental to current efforts could be put in place more quickly.

Armed with the skill descriptions in Table 1 and after examining the various core courses across the curricula, we discovered that there are ample assessment opportunities. Table 2 shows the placement possibilities as a function of the E and ET course types. The professional and experiential courses have the most potential and offer the most flexibility in absorbing the new accreditation requirements. The capstone course which entails a rigorous and open-ended design project warranted a more thorough examination. Both E and ET capstones consist of 5 largely sequential activities that yield a diverse array of assignments enabling all 5 liberal education skills to be measured. Table 2 shows the potential for skill assessment within each of these capstone activities. It should be noted that the capstone is currently a primary source of outcome results for ABET accreditation leading to a concern that it might become overloaded with assessment.

Table 2. Assessment opportunities in core courses.

\begin{tabular}{|l|c|c|c|c|c|}
\hline Course Type & IA & CT & C & IL & PS \\
\hline Professional (E only) & $\checkmark$ & $\checkmark$ & & $\checkmark$ & $\checkmark$ \\
\hline Experiential & $\checkmark$ & $\checkmark$ & $\checkmark$ & $\checkmark$ & $\checkmark$ \\
\hline Theoretical & $\checkmark$ & & & & $\checkmark$ \\
\hline Other (ET only) & $\checkmark$ & & & $\checkmark$ & \\
\hline Capstone Activity & $\checkmark$ & $\checkmark$ & $\checkmark$ & $\checkmark$ & $\checkmark$ \\
\hline (1) Proposal & $\checkmark$ & & $\checkmark$ & $\checkmark$ & \\
\hline (2) Design Elements & $\checkmark$ & $\checkmark$ & $\checkmark$ & & \\
\hline (3) Detailed Design & & $\checkmark$ & & & $\checkmark$ \\
\hline (4) Implementation & & & $\checkmark$ & & $\checkmark$ \\
\hline (5) Reporting Results & & & & $\checkmark$ & \\
\hline
\end{tabular}

Assessment Tools and Placement

The suitability of the VALUE rubrics, either as is or slightly modified, for use in the 5 course types is now addressed. These rubrics contain 5 to 6 specific attributes as illustrated in Table 3 . A description of these attributes may be found on the rubric forms available online. ${ }^{14}$ 
Table 3. VALUE rubric attributes. ${ }^{14}$

\begin{tabular}{|c|c|c|c|c|}
\hline $\begin{array}{l}\text { Inquiry and } \\
\text { Analysis }\end{array}$ & $\begin{array}{l}\text { Critical } \\
\text { Thinking }\end{array}$ & $\begin{array}{l}\text { Creative } \\
\text { Thinking }\end{array}$ & $\begin{array}{c}\text { Information } \\
\text { Literacy }\end{array}$ & $\begin{array}{c}\text { Problem } \\
\text { Solving }\end{array}$ \\
\hline Topic selection & $\begin{array}{l}\text { Explanation of } \\
\text { issues }\end{array}$ & $\begin{array}{l}\text { Acquire } \\
\text { competencies }\end{array}$ & $\begin{array}{l}\text { Extent of } \\
\text { information } \\
\text { needed }\end{array}$ & Define problem \\
\hline $\begin{array}{l}\text { Existing } \\
\text { knowledge, } \\
\text { research \& views }\end{array}$ & Evidence & Take risks & $\begin{array}{l}\text { Access needed } \\
\text { information }\end{array}$ & Identify strategies \\
\hline Design process & $\begin{array}{l}\text { Influence of } \\
\text { context } \\
\text { \& assumptions } \\
\end{array}$ & Solve problems & $\begin{array}{l}\text { Evaluate \& source } \\
\text { critically }\end{array}$ & $\begin{array}{l}\text { Propose solutions } \\
\text { \& hypotheses }\end{array}$ \\
\hline Analysis & $\begin{array}{l}\text { Perspective, thesis } \\
\text { \& hypothesis }\end{array}$ & $\begin{array}{l}\text { Embrace } \\
\text { contradictions }\end{array}$ & $\begin{array}{l}\text { Effectively use to } \\
\text { accomplish a } \\
\text { purpose }\end{array}$ & $\begin{array}{l}\text { Evaluate potential } \\
\text { solutions }\end{array}$ \\
\hline Conclusions & $\begin{array}{l}\text { Conclusions \& } \\
\text { related outcomes }\end{array}$ & Be innovative & $\begin{array}{l}\text { Access \& use } \\
\text { ethically \& } \\
\text { legally }\end{array}$ & $\begin{array}{l}\text { Implement } \\
\text { solution }\end{array}$ \\
\hline $\begin{array}{l}\text { Limitations \& } \\
\text { implications }\end{array}$ & & $\begin{array}{l}\text { Connect, } \\
\text { synthesize } \\
\text { \& transform }\end{array}$ & & $\begin{array}{l}\text { Evaluate } \\
\text { outcomes }\end{array}$ \\
\hline
\end{tabular}

Each VALUE rubric contains an achievement scale from 1 to 4 with commentary to guide the selection of the most appropriate result. To ascertain the degree of suitability as an assessment tool, we examined each rubric according to the following criteria:

- Extent to which the rubric attributes aligned with current course outcomes and evidence of student achievement,

- Ability of the faculty to consistently apply them and whether any specific training would be needed,

- Applicability across E and ET curricula and course types.

We concluded that the VALUE rubrics represent a good starting point for pilot assessment of the 5 new liberal education skills. Some customization will likely be needed for best results in $\mathrm{E}$ and ET courses. Based on the placement opportunities presented earlier in Table 2 and the need to avoid overloading the capstone, an assessment framework was developed. Table 4 shows how the 5 skills could be evaluated, each involving a minimum of 2 course types.

Table 4. Assessment framework for E and ET programs.

\begin{tabular}{|l|c|c|c|c|c|}
\hline Engineering (E) Programs & IA & PS & CT & IL & C \\
\hline Course Type & & & $\checkmark$ & $\checkmark$ & \\
\hline Professional & & $\checkmark$ & & & $\checkmark$ \\
\hline Experiential & $\checkmark$ & $\checkmark$ & & & \\
\hline Theoretical & $\checkmark$ & & $\checkmark$ & $\checkmark$ & $\checkmark$ \\
\hline Capstone & & & & &
\end{tabular}




\begin{tabular}{|l|c|c|c|c|c|c|}
\hline Engineering Technology (ET) Programs \\
\hline Course Type & IA & PS & CT & IL & C \\
\hline Professional & \multicolumn{5}{|c|}{ None in current curricula } \\
\hline Experiential & & $\checkmark$ & $\checkmark$ & & $\checkmark$ \\
\hline Theoretical & $\checkmark$ & $\checkmark$ & & & \\
\hline Capstone & $\checkmark$ & & $\checkmark$ & $\checkmark$ & $\checkmark$ \\
\hline Other & & & & $\checkmark$ & \\
\hline
\end{tabular}

A pilot targeting 3 skills: creative thinking, critical thinking and problem solving was aided by Bommarju et al. who described some of the challenges that faculty face in assessing liberal education concepts. ${ }^{15}$ Lansari et al. showed how the measurement of problem solving and critical thinking skills could be incorporated into an Information Systems curriculum. ${ }^{16}$ Ralston discussed the relationship between critical thinking and ABET outcomes that led to specific rubrics being developed and validated. ${ }^{17}$

An internal curricular strategy, Improved Capstone (ICap), served as a valuable foundation. ${ }^{18}$ Starting in 2005, ICap was implemented in 2 ET programs whereby experiential courses sequentially introduce challenging and open-ended assignments that foster cognitive learning. ICap courses contain an assessment methodology that measures 4 of the "intellectual and practical" skills. The presence of these courses and their associated evaluation tools were useful. One challenge that quickly came to light in planning a pilot was the availability of appropriate student work products in the capstone. None of the existing written documents seemed very useful to evaluate any of the 3 skill areas for a pilot. However, an interesting idea surfaced regarding the team status meetings with the instructor in which an interview Q\&A style could be used to gather sufficient evidence.

A pilot was conducted in spring 2010 involving the capstone for Electrical Engineering as well as Computer Engineering majors. The face-to-face meetings with the teams provided an excellent opportunity to evaluate the skill levels. The instructor reported that each team employed all 3 skills at one or more point(s) during the semester. The results are shown in Table 5 for all 6 teams. Good performance was observed in 2-3 teams for each skill; however, the best teams were not always the same. No team demonstrated low achievement in any area; indicative of either a strong set of students or a lack of training on the part of the instructor.

Table 5. Pilot assessment results.

\begin{tabular}{|l|c|c|c|}
\hline Capstone Team & PS (1-4 scale) & CT (1-4 scale) & C (1-4 scale) \\
\hline (1) Bluetooth FM transmitter & 3.8 & 3.8 & 3.3 \\
\hline (2) Neural network pump reliability prediction & 4.0 & 4.0 & 3.6 \\
\hline (3) Wireless super-heterodyne radio & 3.3 & 2.8 & 3.1 \\
\hline (4) Wireless power transfer & 3.1 & 3.1 & 3.6 \\
\hline (5) Autonomous fire-fighting robot & 3.6 & 2.8 & 3.1 \\
\hline (6) Microwave electromagnetic curing model & 3.3 & 3.6 & 3.1 \\
\hline Overall average & 3.5 & 3.4 & 3.3 \\
\hline
\end{tabular}




\section{Conclusion}

In response to mandates from NEASC, our new academic mission, and a desire to integrate liberal and professional education, we have undertaken a project to identify core undergraduate learning outcomes, to be addressed and assessed in general education and each major. The planning and actions undertaken thus far at both the university and engineering program levels to meet this new requirement are described. Outcome assessment has been expanded to include 5 "intellectual and practical skills," specifically, critical/creative thinking, inquiry/analysis, problem-solving, and information literacy. A framework showing where the best opportunities to measure student achievement level within core courses is presented. A recent pilot, employing the VALUE rubrics and targeting 3 of the 5 skills, was successful in identifying a method to observe and measure achievement. Future work on assessment methods and their placement as well as pilots are planned.

\section{Bibliography}

1. New England Association for Schools and Colleges, "Standards for Accreditation," Bedford, MA, 2006.

2. Humphreys, D., "Making the Case for Liberal Education: Responding to Challenges," Association of American Colleges and Universities, Washington, DC, 2010.

3. Derek Bok, "Our Underachieving Colleges: A Candid Look at How Much Students Learn and Why They Should Be Learning More,” Princeton University Press, Princeton, NJ, 2006.

4. Arum, R., and Roksa, J. “Academically Adrift: Limited Learning on College Campuses,” University of Chicago Press, Chicago, IL, 2011.

5. Valenzuela, M., Allen, J. and Swenty, B., "Liberal Education: A Survey of Goals," Proceedings of the 2008 ASEE National Conference and Exposition, Pittsburgh, PA, Paper AC 2008-973.

6. Commission on the Future of Higher Education, "A Test of Leadership: Charting the Future of U.S. Higher Education,” U.S. Department of Education, Washington, DC, 2006.

7. AACU Board of Directors, The Quality Imperative: Match Ambitious Goals for College Attainment with an Ambitious Vision for Learning, Association of American Colleges and Universities, 2010.

8. Greater Expectations: A New Vision for Learning as a Nation Goes to College, Association of American Colleges and Universities, Washington, DC, 2002.

9. Liberal Education and America's Promise (LEAP): Excellence for Everyone as a Nation Goes to College, Association of American Colleges and Universities, Washington, DC, 2005.

10. Peter D. Hart Research Associates, "How Should Colleges Assess and Improve Student Learning: Employers' Views on the Accountability Challenge," Association of American Colleges and Universities, Washington, DC, 2008.

11. Association of American Colleges and Universities, "College Learning for the New Global Century: A Report from the National Leadership Council for Liberal Education and America's Promise," Association of American Colleges and Universities, Washington, DC, 2007.

12. Deborah Nusche, Assessment of Learning Outcomes in Higher Education: A comparative Review of Selected Practices, Organization for Economic Co-operation and Development (OECD) Directorate for Education, 2008.

13. President Barack Obama, "Remarks by the President on the American Graduation Initiative," http://www.whitehouse.gov/the_press_office/Remarks-by-the-President-on-the-AmericanGraduation-Initiativein-Warren-MI/, Accessed March 1, 2011.

14. Newman, J. H. “The Idea of a University,” Longmans and Green, London, England, 1873 (Re-printed in 1947).

15. Heywood, J., "Engineering Literacy: A Component of Liberal Education,” Proceedings of the 2010 ASEE National Conference and Exposition, Louisville, KY, Paper AC 2010-1505.

16. Harper, B., Lattuca, L., Yin, A. and Terenzuini, P., "Liberal Education for the Engineer of 2020: Are Administrators on Board?," Proceedings of the 2010 ASEE National Conference and Exposition, Louisville, KY, Paper AC 2010-1335.

17. VALUE rubrics, <http://www.aacu.org/VALUE/rubrics/index_p.cfm> Retrieved December 28, 2010. 
18. Rhodes, T. L., “Assessing Outcomes and Improving Achievement: Tips and Tools for Using Rubrics," Association of American Colleges and Universities, Washington, DC, 2010.

19. Bommaraju, S., Earley, R. and Hergert, D., "Incorporating Liberal Education Concepts into Engineering Technology Senior Design Course,” Proceedings of the 2003 ASEE National Conference and Exposition, Nashville, TN, Session 502.

20. Lansari, A., Al-Rawi, A., Tubaishat, A. and Bouslama, F., "A Course Sequence for Integrating Problem Solving and Critical Thinking in a Hybrid Outcome-Based IS/IT Curriculum," Proceedings of the 2008 ASEE National Conference and Exposition, Pittsburgh, PA, Paper AC 2008-1581.

21. Ralston, P. and Bays, C., "Refining a Critical Thinking Rubric for Engineering," Proceedings of the 2010 ASEE National Conference and Exposition, Louisville, KY, Paper AC 2010-1518.

22. Eppes, T., Milanovic, I. and Sweitzer, F., “Strengthening Capstone Skills in STEM Programs,” Journal of Innovative Higher Education, 37(1), 2011. 